\title{
Now Disease Reports \\ Natural occurrence of Clerodendron yellow mosaic virus on Bougainvillea in India
}

Chitra Nehra, Anurag Kumar Sahu, Avinash Marwal and R.K. Gaur*

Department of Science, Faculty of Arts, Science and Commerce, Mody University of Science and Technology, Lakshmangarh, Sikar-332311, Rajasthan, India

*E-mail: gaurrajarshi@hotmail.com

Received: 21 Jul 2014. Published: 25 Oct 2014. Keywords: begomovirus, ClYMV, phylogenetic analysis

Bougainvillea (Bougainvillea peruviana) is a common and popular ornamental plant of the family Nyctaginaceae commonly grown in the gardens of India. During a survey in the spring seasons of 2012 and 2013 bougainvillea plants throughout Rajasthan State, India exhibited typical symptoms for a begomovirus infection, including leaf curling and stunted growth (Fig. 1). Total DNAs were extracted from leaf samples of ten symptom-bearing and one symptomless plant, and analysed by PCR using virus component-specific primers (Wyatt \& Brown, 1996). Agarose ge electrophoresis of the PCR products showed amplicons of the expected size $(\sim 550 \mathrm{bp})$ suggesting the presence of DNA-A genomic components in the plants exhibiting symptoms. Efforts to detect DNA-B components and associated satellite molecules were also made by PCR using specific primers, PCRc1/PBL1v2040 (Rojas et al., 1993) and beta01/beta02 (Briddon et al., 2002), respectively, but were not successful.

PCR-positive samples were subjected to rolling circle amplification (RCA, TempliPhi kit, GE healthcare, USA) to obtain the full-length vira genomes. RCA products were digested with EcoRI, BamHI, HindIII, Sal1, $X h o \mathrm{I}, P s t \mathrm{I}$ and $X b a \mathrm{I}$. After gel electrophoresis all the ten samples showed single fragments of $\sim 2.7 \mathrm{kbp}$, which were cloned into pGEMT vector using EcoRI restriction sites. Five independent clones (one clone/plant) were sequenced and showed 100\% identity with each other (GenBank Accession No. KF704391). Sequence analysis of DNA-A revealed 98\% identity at nucleotide level with Clerodendron yellow mosaic virus (CIYMV) isolates (Fig. 2) suggesting that our isolate is an isolate of ClYMV. To the best of our knowledge this is the first report of natural occurrence of CIYVM on $B$. peruviana in India. However, there is a need for more detailed study about
ClYMV as it is broadening its host range

\section{Acknowledgements}

The authors express their thanks for financial support to the Council of Scientific and Industrial Research (file no 09/1064 (0002)/2013-EMR-1)

\section{References}

Briddon RW, Bull SE, Mansoor S, Amin I, Markham PG, 2002. Universal primers for the PCR-mediated amplification of DNA $\beta$. Molecular Biotechnology 20, 315-318. http://dx.doi.org/10.1385/MB:20:3:315

Manen JF, Sinitsyna O, Aeschbach L, Markov AV, Sinitsyn A, 2005. A fully automatable enzymatic method for DNA extraction from plant tissue. BMC Plant Biology 5, 23. http://dx.doi.org/10.1186/1471-2229-5-23

Rojas MR, Gilbertson RL, Russell DR, Maxwell DP, 1993. Use of degenerate primers in the polymerase chain reaction to detect whitefly transmitted geminiviruses. Plant Disease 77, 340-347.

http://dx.doi.org/10.1094/PD-77-0340

Tamura K, Peterson D, Peterson N, Stecher G, Nei M, Kumar S, 2011. MEGA5: Molecular evolutionary genetics analysis using maximum likelihood, evolutionary distance, and maximum parsimony methods. Molecular Biology and Evolution 28, 2731-2739. http://dx.doi.org/10.1093/molbev/msr121

Wyatt SD, Brown JK, 1996. Detection of subgroup III geminivirus isolates in leaf extracts by degenerate primers and polymerase chain reaction. Phytopathology 86, 1288-1293. http://dx.doi.org/10.1094/Phyto-86-1288

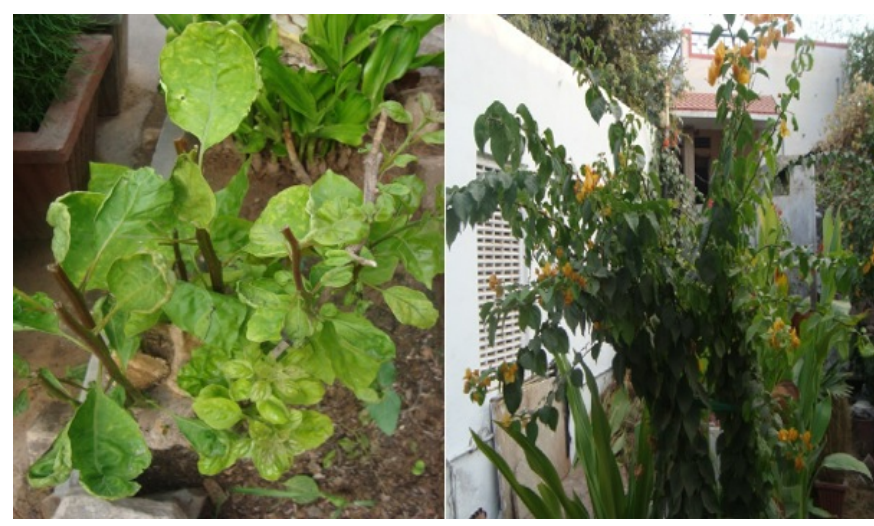

Figure 1

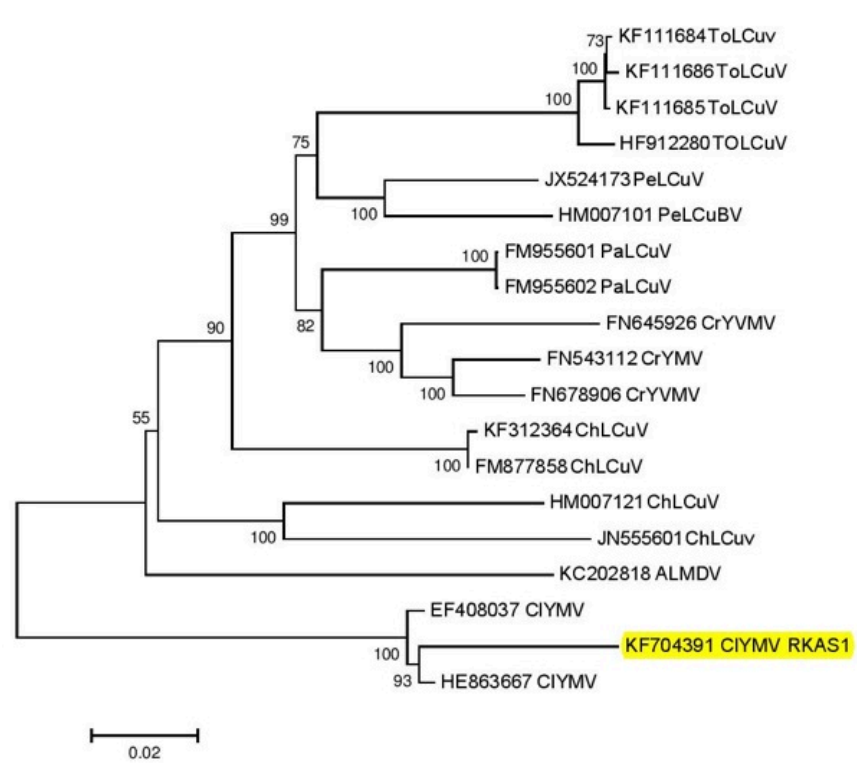

Figure 2

To cite this report: Nehra C, Kumar Sahu A, Marwal A, Gaur RK, 2014. Natural occurrence of Clerodendron yellow mosaic virus on Bougainvillea in India. New Disease Reports 30, 19. http://dx.doi.org/10.5197/j.2044-0588.2014.030.019 